\title{
Does spatial distribution of tree size account for spatial variation in soil respiration in a tropical forest?
}

\author{
Laëtitia Bréchet, Stéphane Ponton, Tancrède Alméras, Damien Bonal, Daniel Epron
}

\begin{abstract}
We explored the relationship between soil processes, estimated through soil respiration $\left(R_{\text {soil }}\right)$, and the spatial variation in forest structure, assessed through the distribution of tree size, in order to understand the determinism of spatial variations in $R_{\text {soil }}$ in a tropical forest. The influence of tree size was examined using an index $\left(I_{c}\right)$ calculated for each tree as a function of (1) the trunk cross section area and (2) the distance from the measurement point. We investigated the relationships between $I_{c}$ and litterfall, root mass and $R_{\text {soil }}$, respectively. Strong significant
\end{abstract}

L. Bréchet $(\bowtie) \cdot S$. Ponton $\cdot$ T. Alméras $\cdot$ D. Bonal

INRA, UMR Ecologie des Forêts de Guyane,

Campus Agronomique, BP 709,

97387 Kourou cedex, French Guiana

e-mail: laetitiabrechet@yahoo.fr

S. Ponton $\cdot$ D. Bonal $\cdot$ D. Epron

INRA, UMR 1137, Ecologie et Ecophysiologie Forestières,

Centre de Nancy,

54280 Champenoux, France

T. Alméras

CNRS, UMR Laboratoire de mécanique et génie civil,

Université Montpellier 2,

34095 Montpellier cedex, France

S. Ponton $\cdot$ D. Bonal $\cdot$ D. Epron

Nancy Université, Université Henri Poincaré, UMR 1137,

Ecologie et Ecophysiologie Forestières,

Faculté des Sciences,

54500 Vandoeuvre les Nancy, France relationships were found between $I_{c}$ and both litterfall and root mass. $R_{\text {soil }}$ showed a large range of variations over the 1-ha experimental plot, from 1.5 to $12.6 \mathrm{~g}_{\mathrm{C}}$ $\mathrm{m}^{-2} \mathrm{~d}^{-1}$. The best relationship between $I_{c}$ and $R_{\text {soil }}$ only explained $17 \%$ of the spatial variation in $R_{\text {soil }}$. These results support the assumption that local spatial patterns in litter production and root mass depend on tree distribution in tropical forests. Our study also emphasizes the modest contribution of tree size distribution-which is mainly influenced by the presence of the biggest trees (among the large range size of the inventoried trees greater than $10 \mathrm{~cm}$ diameter at $1.30 \mathrm{~m}$ above ground level or at $0.5 \mathrm{~m}$ above the buttresses)-in explaining spatial variations in $R_{\text {soil }}$.

Keywords Forest structure - Soil respiration - Root mass $\cdot$ Litterfall $\cdot$ Spatial variation $\cdot$ Tropical forest

\section{Introduction}

Since soil respiration $\left(R_{\text {soil }}\right)$ in forest ecosystems accounts for approximately $25 \%$ of the global carbon dioxide exchange (Raich and Potter 1995; Raich and Schlesinger 1992), even more than fossil fuel emissions and deforestation (van der Werf et al. 2009), $R_{\text {soil }}$ is a key component in the global carbon cycle. Obtaining accurate estimates of $R_{\text {soil }}$ is thus crucial to understanding the global carbon budget, particularly in tropical forests which represent a quarter of the 
carbon stocks in terrestrial ecosystems (Dixon et al. 1994). Furthermore, from a global climate change perspective, reliable carbon balance predictions using mechanistic models will only become possible if the processes leading to soil carbon emissions are fully understood.

Soil respiration is the result of a large set of biological processes, predominantly root-derived respiration and decomposition of soil organic matter, aboveground litter and belowground litter by the microbial community. As a consequence, the determinants of the variation in soil respiration are numerous and diverse and may involve several processes or interactions. Spatial variations in $R_{\text {soil }}$, especially those occurring over short distances, have tended to be neglected in comparison with temporal variations (Metcalfe et al. 2007; Sotta et al. 2004). The main factors influencing spatial variation already identified are: soil moisture (Adachi et al. 2005; Martin and Bolstad 2009; Schwendenmann et al. 2003); physical soil properties that control gas diffusivity and nutrient availability (Epron et al. 2006; Kosugi et al. 2007; Silver et al. 2005); and soil topography, which strongly impacts both soil water content and physical soil properties (Epron et al. 2006; Chambers et al. 2004). Furthermore, it has been suggested that small-scale spatial variations in $R_{\text {soil }}$ (from a few centimetres to around $10 \mathrm{~m}$ ) could be influenced by biotic factors. Indeed, the spatial distribution of organic detritus (which fuels microbial respiration), decomposers or respiring organisms is not necessarily uniform, either in quantity or in quality (Epron et al. 2004; Ohashi et al. 2007). It has been shown that spatial differences in plant productivity and litter supply influence soil biota and, consequently, decomposition processes (NegreteYankelevich et al. 2006). At the ecosystem level, positive relationships between root biomass and $R_{\text {soil }}$ have been observed in tropical forests (Epron et al. 2006; Fang et al. 1998; Janssens et al. 1998; Metcalfe et al. 2007). Microbial respiration also makes an important contribution to total $R_{\text {soil }}$. For instance, it accounted for between 65 and $76 \%$ in Brazilian lowlands (Silver et al. 2005). As microbes feed on aboveground litter and other material, the quantity and quality of litter production (e.g. $\mathrm{P}$ and $\mathrm{N}$ contents) could also be a key factor in determining spatial variations in $R_{\text {soil }}$ (Bréchet et al. 2009; Epron et al. 2004). Trees are involved, either directly (i.e. root respiration) or indirectly (i.e. root-derived rhizosphere respiration, production of carbon substrates for microbial respiration), in most of the processes contributing to $R_{\text {soil }}$.

Because large surveys of root biomass and litter are virtually impossible to conduct at the regional scale, a proxy for litterfall and root biomass which would explain spatial variations in $R_{\text {soil }}$, is required. The spatial distribution of tree diameter is a good candidate. A theoretical framework was successfully developed to describe the spatial influence of trees on ecosystem characteristics such as canopy coverage in a boreal Scots pine forest (Kuuluvainen and Linkosalo 1998). In tropical wet forests, the very high tree species diversity might favour patchiness of soil conditions. Alternatively, the high level of competition for soil nutrients among plants might induce a relatively regular distribution of roots over the entire available volume of soil. Regarding litter variation, Guehl et al. (1998) found that the lateral dispersal and mixing of leaves after fall result in a homogeneous composite of litterfall properties on the soil surface (this would, in turn, likely favour a uniform distribution of roots). Therefore, the existence of a relationship between tree distribution and the two main inputs of carbon in the soil, namely litterfall and root biomass, is not straightforward in this particular context and needs to be tested.

Besides the effect of the quantity of aboveground litter and root-derived inputs to the soil, the specific qualitative characteristics of trees are also likely to influence soil respiration. However, testing for a species-specific effect can be exceedingly challenging in tropical forests where most of the tree species occur only once per hectare. We hypothesized that the spatial distribution of tree size in itself might explain a significant part of the spatial heterogeneity of soil respiration. Indeed, several recent studies have emphasized the relationships between tree dimension parameters (i.e. tree diameter or basal area) and $R_{\text {soil }}$ in temperate (Soe and Buchmann 2005; Vincent et al. 2006) and tropical forests (Katayama et al. 2009) or tropical plantations (Bréchet et al. 2009).

The main objective of this study was to analyse the influence of forest structure (size and spatial distribution of the trees) on spatial variations in $R_{\text {soil }}$ in a tropical rainforest in French Guiana. We hypothesized that the spatial distribution of tree size would account for the spatial variability in root mass and litterfall. 
Therefore, we examined the relationships between tree size distribution and both litterfall and root mass, then explored the relationship between tree size distribution and soil respiration. To tackle these questions, we first described the spatial variation in $R_{\text {soil }}$ within a plot of approximately $9,800 \mathrm{~m}^{2}$. The plot was undisturbed forest characterised by homogeneous soil texture. The position and circumference of all trees were measured. Ancillary litterfall and root mass data were also gathered from the same plot. Sampling was designed to allow $R_{\text {soil }}$ to be characterised at two different spatial levels by distributing 325 measurement points over 25 subplots.

\section{Materials and methods}

Study site

Our investigations were carried out in the Paracou forest in French Guiana (5'16 $54^{\prime \prime} \mathrm{N}, 52^{\circ} 54^{\prime} 44^{\prime \prime} \mathrm{W}$; Gourlet-Fleury et al. 2004) on an experimental plot $\left(9,800 \mathrm{~m}^{2}\right.$ with an extension around the measurement points) located within the footprint of an eddyflux tower (Guyaflux site; Bonal et al. 2008). The soil is mainly a nutrient-poor acrisol (FAO-ISRIC-ISSS 1998) developed over the Precambrian schists in the Bonidoro-series. The coarse sandy texture of the soil decreases slightly with depth (55.3 to $50.4 \%$ from 2 to $20 \mathrm{~cm}$ below the surface) while the clay content increases $(21.8$ to $26.4 \%)$. The forest floor and the soil are homogeneous throughout the plot (Freycon, pers. comm.).

The wet tropical climate is strongly influenced by the north/south movements of the Inter-Tropical Convergence Zone (ITCZ). The seasonal movements of the ITCZ induce two contrasting periods: a long dry season, occurring from mid-August to mid-November, and a rainy season the rest of the year interrupted by a short dry season in February/March. The mean annual precipitation recorded at the site over the 1979-2001 period was 3,041 $\mathrm{mm}$ (Gourlet-Fleury et al. 2004). The mean annual air temperature is $25.7^{\circ} \mathrm{C}$ with little seasonal variation $\left(1.5^{\circ} \mathrm{C}\right.$; Bonal et al. 2008).

Plot characterisation

In the experimental plot, the circumferences of all trees were measured at $1.30 \mathrm{~m}$ above ground level or at $0.5 \mathrm{~m}$ above the buttresses. Circumferences were converted to diameter assuming a circular section (hereafter referred to as diameter at breast height, $\mathrm{dbh})$. Trees with a dbh $<10 \mathrm{~cm}$ were not considered in our analyses. The geographic coordinates of each tree were recorded (Fig. 1). The spatial distribution of $\mathrm{dbh}$ was then assessed from directional semivariograms calculated for four directions: $0^{\circ}, 45^{\circ}, 90^{\circ}$ and $135^{\circ}$ (from North). As none of the four semivariograms showed a clear pattern (i.e. an increase from the point of origin to a distinct threshold) it was concluded that the distribution of tree size was not spatially structured inside the plot. More than half of the 809 inventoried trees belonged to three dominant botanical families: Sapotaceae (23\%), Lecythidaceae (20\%) and Caesalpiniaceae (11\%).

Litter production (including leaves, small branches, fruits and flowers) was estimated from eight $0.45-\mathrm{m}^{2}$ litter traps installed $1.50 \mathrm{~m}$ above the soil (Fig. 1). Over 4 years (December 2003-January 2008), litter was collected twice a month, dried at $60^{\circ} \mathrm{C}$ until constant mass was achieved (around $72 \mathrm{~h}$ ) and weighed.

Root samples were collected in five locations in one-half of the plot (Fig. 1) in early May 2006, following a two-step sampling procedure. First, a 7-cm-diameter core was taken to precisely estimate fine root mass in the $0-15 \mathrm{~cm}$ and the $15-30 \mathrm{~cm}$ soil layers. The roots were separated from the soil by flotation and sieved through a $0.5-\mathrm{mm}$ screen. Second, a larger volume of soil was extracted with a metallic cubic box of $30 \mathrm{~cm}$ to a side to estimate total root mass. The soil samples were sieved through a $6.3-\mathrm{mm}$ screen. The roots were sorted into three diameter classes: (1) coarse roots (diameter $>10 \mathrm{~mm}$ ), (2) small roots $(10>$ diameter $>2 \mathrm{~mm}$ ) and (3) fine roots (diameter $<2 \mathrm{~mm}$ ). They were washed and ovendried (until reaching constant mass) at $55^{\circ} \mathrm{C}$ for fine roots and $105^{\circ} \mathrm{C}$ for small and coarse roots.

\section{Soil respiration}

Twenty-five circular subplots were set up to characterise the spatial variation in soil respiration, $R_{\text {soil }}$ (Fig. 1). The surface area of each subplot was $78.5 \mathrm{~m}^{2}$ (i.e. $5 \mathrm{~m}$ radius). The 25 subplots were positioned so that they exhibited a continuous gradient in the cumulated trunk cross section area of the encompassed trees. Among the 25 subplots, the trunk cross section area varied 
Fig. 1 a) Schematic overview of the experimental plot showing the position of trees (open circles), litter traps (filled black circles), root mass sampling subplots (filled grey circles) and soil respiration measurement subplots (dotted circles). b) Enlargement of a soil respiration subplot showing the 13 PVC collars

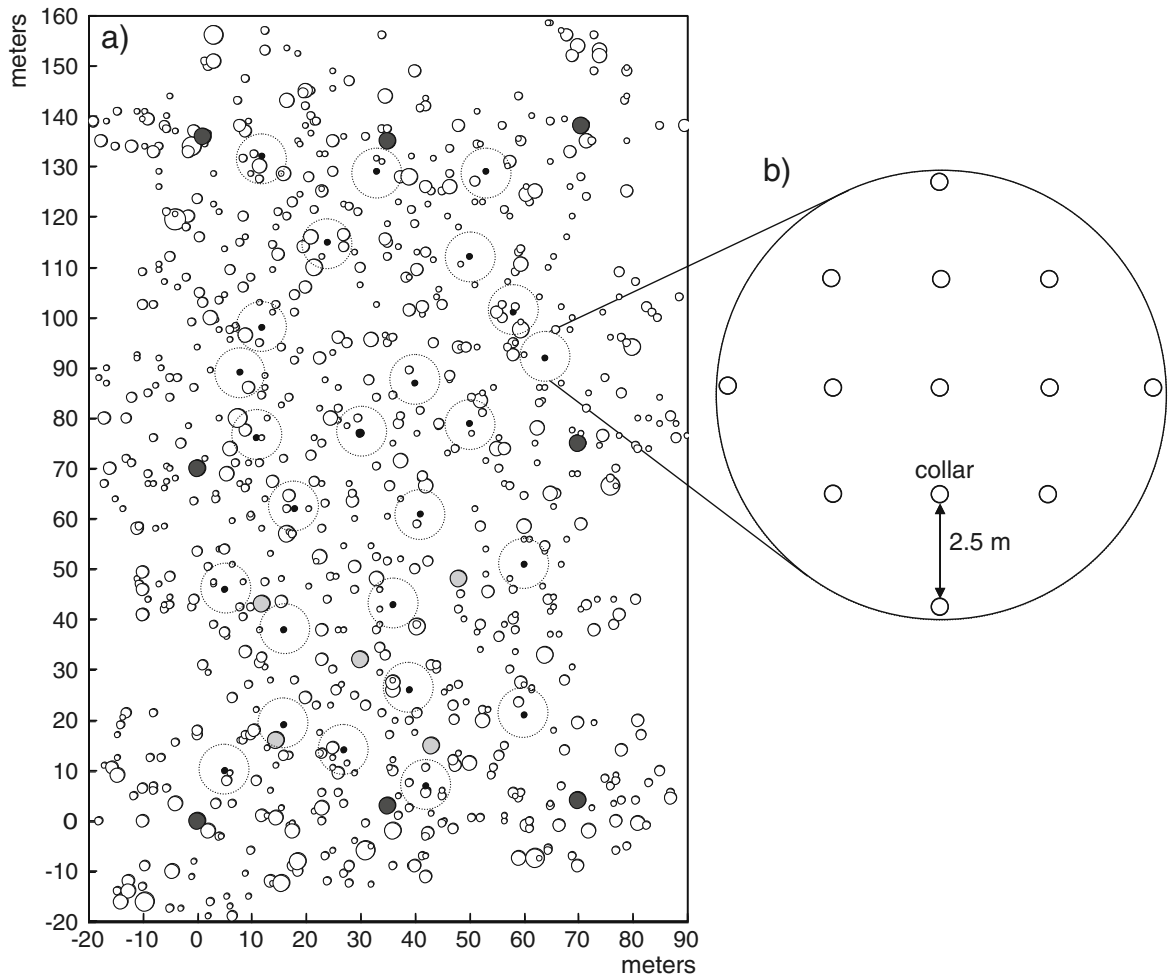

from 0.00 to $1.57 \mathrm{dm}^{2} \mathrm{~m}^{-2}$ and averaged $0.43 \mathrm{dm}^{2}$ $\mathrm{m}^{-2}$. In 2006, about 1 month before taking the $R_{\text {soil }}$ measurements, 13 polyvinyl chloride (PVC) collars (284 $\mathrm{cm}^{2}$ each), spaced $2.5 \mathrm{~m}$ apart, were inserted into the soil at a depth of 2-3 cm in each subplot.

Soil respiration was measured as described in Bréchet et al. (2009). Briefly, the system consisted of an EGM-4 infra-red gas analyzer (PP-Systems, Hitchin, UK) connected to a laboratory-made chamber (a $5.0 \mathrm{dm}^{3}$ PVC cylinder $20 \mathrm{~cm}$ in diameter and $16 \mathrm{~cm}$ in height). Air was circulated between the analyzer and the chamber at a flow rate of $0.3 \mathrm{~L} \mathrm{~min}^{-1}$. The total chamber volume, including the collar space, was calculated for each measurement and averaged $6.3 \mathrm{dm}^{3}$. Measurements were recorded for $240 \mathrm{~s}$ and fluxes were calculated automatically by the EGM program, with the quadratic fit option. Measurements were taken between July 28th and August 4th, which corresponds to the wet-to-dry season transition characterised by high $R_{\text {soil }}$ values (Bonal et al. 2008). Measurements were conducted between 9:00 a.m. and 4:30 p.m. A single rain event occurred during this period $(10.4 \mathrm{~mm})$ on July 30th at 3:00 p.m.: measurements were interrupted and resumed the next day.

\section{Data analysis}

Differences in soil respiration among subplots were tested with a mixed model where subplot was considered as a random effect. Spatial variation in $R_{\text {soil }}$ within subplots was assessed with a coefficient of variation $(\mathrm{CV})$ calculated as the square root of the residual variance estimate (i.e. 1.40) divided by the mean, while for between-subplot spatial variation in $R_{\text {soil, }}$, we calculated $\mathrm{CV}$ as the square root of the variance estimate (i.e. 0.59 ) divided by the mean. To test the influence of individual trees (via their above/ belowground and alive/dead masses) on soil processes, an index of local contribution $\left(I_{c}\right)$ was calculated for each tree, as a function of its trunk cross section area and the distance from the measurement collars, following the approach that was developed by Kuuluvainen and Linkosalo (1998) in a natural Scots pine forest in Finland. Five models describing the change in $I_{c}$ with measurement point distance from the tree were tested (namely uniform, linear, parabolic, power and exponential; Table 1). The implicit assumptions in this calculation were as follows: 1) the tree influence is isotropic, 2) the trees contribute independently from each other, and 3) the contribu- 
tion of a given tree is proportional to its trunk cross section area. Ontogenic and species-specific effects were not considered. For these models, we also assumed that all trees had the same radius of influence, $r$ (i.e. the distance above which their contribution could be neglected). A sixth model was also tested, based on the power formula but where the radius of influence depended on the diameter of the tree (Table 1). The calculation of this radius $\left(r_{\max }\right)$ includes an asymptotic function, restricting the radius of influence to a threshold value, and a constant coefficient " $b$ ", which described the strength of the increase in influence with tree size.

The relationships between litterfall, root mass or soil respiration and the sum of the $I_{c}$ (noted $\sum I_{c}$ and representing the influence of the surrounding trees, according to the tested model) were assessed by using the coefficient of determination as a criterion to select the best model. When the number of parameters was different between two models, we used the F-test developed by Brown and Rothery (1994) to perform the comparison and to select the most appropriate models (Epron et al. 2004). Relationships with soil respiration were analysed at both collar and subplot levels. In the latter case, the average soil respiration $(n=13)$ was related to $\sum I_{c}$ calculated from the centre of the subplot.

\section{Results}

The annual litterfall averaged $1,097 \pm 243 \mathrm{~g}_{\mathrm{DM}} \mathrm{m}^{-2} \mathrm{y}^{-1}$ and ranged from 648 to $1,378 \mathrm{~g}_{\mathrm{DM} \mathrm{m}} \mathrm{m}^{-2} \mathrm{y}^{-1}$ across the study plot ( $n=8$ litter traps). A significant relationship was observed between the 4-year average annual litterfall (calculated for each of the eight litter traps) and the sum of local contribution indices of surrounding trees within the fitted radius of influence $\left(\sum I_{c}\right)$ according to a uniform model. The fitted radius of influence $(r)$ was $7 \mathrm{~m}$ (Table $1 ; \mathrm{R}^{2}=0.61, p<0.05$ for M1, $n=8$; Fig. 2a and b).

Total root mass in the $0-30 \mathrm{~cm}$ soil layer varied from 1,282 to $3,150 \mathrm{~g}_{\mathrm{DM} \mathrm{m}} \mathrm{m}^{-2}$ with an average of $2,027 \pm 796 \mathrm{~g}_{\mathrm{DM}} \mathrm{m}^{-2}(n=5)$. The linear model with $r$ set at $7 \mathrm{~m}$ provided the best correlation between root mass and $\sum I_{c}$ (Table $1 ; \mathrm{R}^{2}=0.94, p<0.01$ for $\mathrm{M} 2$, $n=5$; Fig. 2c and d).

Over the whole study plot, the average rate of soil respiration was $4.7 \pm 1.5 \mathrm{~g}_{\mathrm{C}} \mathrm{m}^{-2} \mathrm{~d}^{-1}(n=319)$, with an 

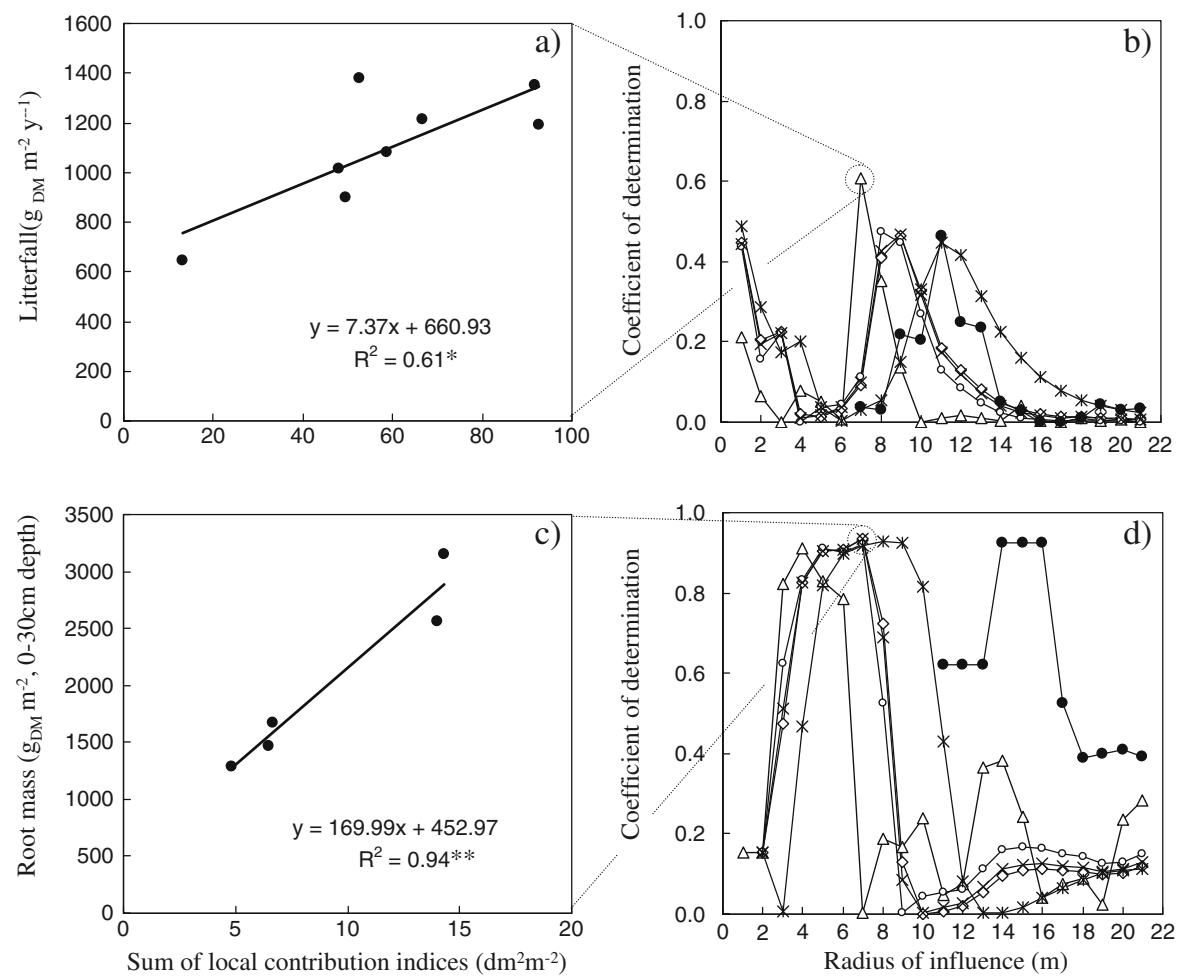

Fig. 2 Relationships between the sum of local contribution indices of surrounding trees within the fitted radius of influence $\left(\sum I_{c}\right)$ and a) litterfall or c) root mass. The best relationships obtained with M1 $(p<0.05, n=8)$ for litterfall and M2 for root mass $(p<0.01, n=5)$ are shown here. Variations in the strength of the relationship between $\sum I_{c}$ and b) litterfall $(n=8)$ or $\left.\mathbf{d}\right)$ root mass $(n=5)$, according to the radius of influence of the trees used in the calculation of the index. The strength of the relationship was assessed through the coefficient of determina-

8-fold variation, from 1.5 to $12.6 \mathrm{~g}_{\mathrm{C}} \mathrm{m}^{-2} \mathrm{~d}^{-1}$. The frequency distribution of the soil respiration rate was slightly skewed towards lower values at collar level $(n=320)$ and at the subplot level $(n=25$; Fig. 3$)$. The within-subplot variation (calculated as the residual variance of a mixed model with subplot considered as a random effect) was $30 \%$ relative to average $R_{\text {soil }}$, and about twice the between-subplot variation (c.a. $13 \%$, calculated as the variance attributed to the random effect 'subplot').

There was no correlation between mean $R_{\text {soil }}$ and trunk cross section area of the subplots. When considering soil respiration at the collar level, $R_{\text {soil }}$ only correlated weakly with $\sum I_{c}$, whatever the model, with a maximum $\mathrm{R}^{2}$ of 0.05 obtained with M6 $\left(p<0.0001\right.$ for $a=1.4, b=0.00026$ and $r_{\max }=16 \mathrm{~m}$, $n=319$, Fig. $4 \mathrm{a}$ and b). At the subplot scale, only one tion $\left(\mathrm{R}^{2}, * p<0.05\right.$ and $\left.* * p<0.01\right)$ of the linear regression between the tree local contribution index and the litterfall or root mass. Six different models for local contribution were tested, namely uniform (open triangle, M1), linear (open diamond, M2), parabolic (open circle, M3), power (black cross, M4), exponential (black star, M5) and power with $r_{\max }$ limit (maximum radius of influence depending on the size of tree; black circle, M6)

model (M6) out of six used to calculate $I_{c}$ showed significant correlation between $\sum I_{c}$ and $R_{\text {soil }}$ (Table 1; Fig. $4 \mathrm{c}$ and $\mathrm{d})$. The best correlation $\left(\mathrm{R}^{2}=0.17, p<0.05\right.$, $n=25$ ) was obtained with the following adjustment: $a=1.8, b=0.00026$ and $r_{\max }=12 \mathrm{~m}$, which corresponds to $r=0.2 \mathrm{~m}$ for a small tree $(\mathrm{dbh}=10 \mathrm{~cm})$ and $r=10.2 \mathrm{~m}$ for the biggest trees in the subplot $(\mathrm{dbh}=97 \mathrm{~cm})$.

\section{Discussion}

Spatial variation in soil respiration

The mean soil respiration measured in this study $\left(4.7 \pm 1.5 \mathrm{~g}_{\mathrm{C}} \mathrm{m}^{-2} \mathrm{~d}^{-1}\right)$ was similar to the one estimated by Epron et al. (2006) in the same forest and on the same soil $\left(4.7 \pm 2.1 \mathrm{~g}_{\mathrm{C}} \mathrm{m}^{-2} \mathrm{~d}^{-1}\right)$ and was of the same 

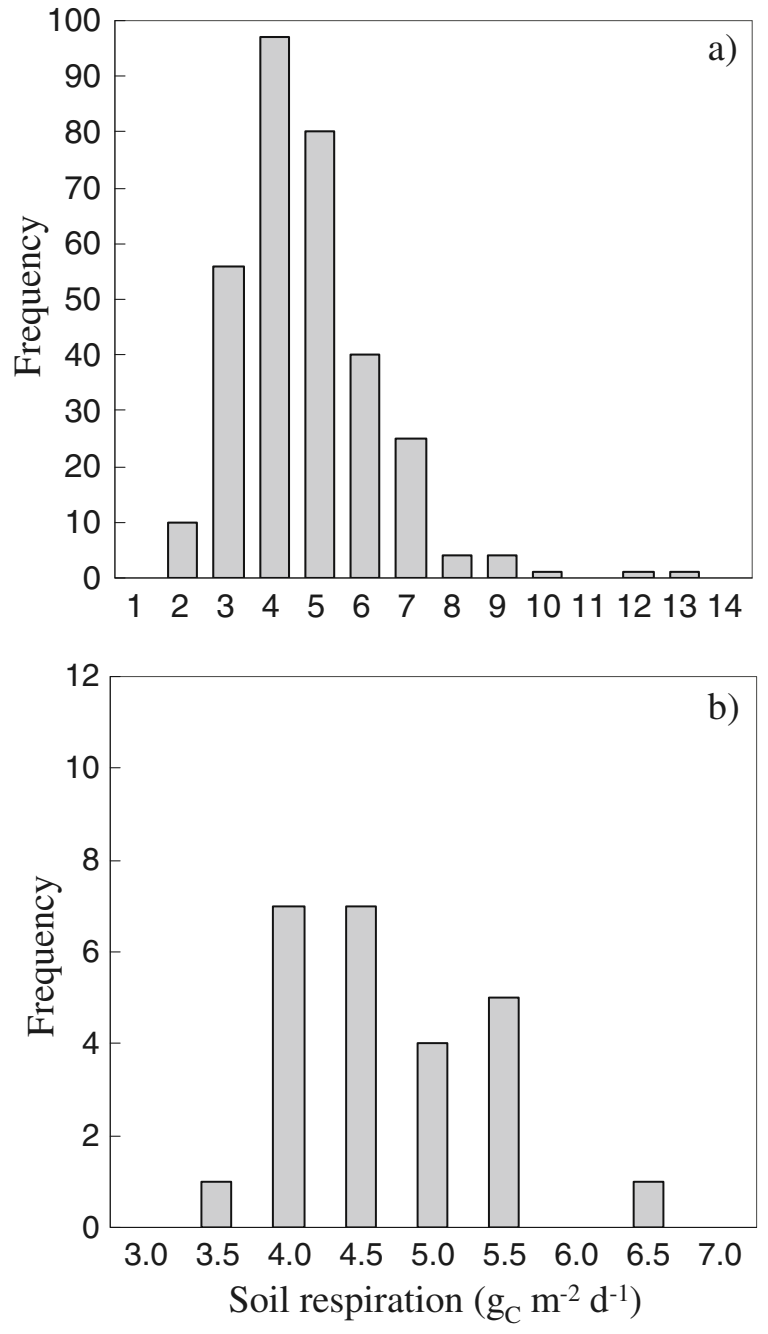

Fig. 3 Frequency distribution of soil respiration at a) collar scale $(n=319)$ and b) subplot scale $(n=25)$

order of magnitude as other tropical forest measurements (Buchmann et al. 1997; Chambers et al. 2004; Davidson et al. 2000; Sotta et al. 2004). A comparison of the spatial variation in soil respiration between studies is difficult because of different sampling designs (i.e. subplot size, measurement grid) and periods of measurement (i.e. season, duration). In this study, we measured soil respiration over nearly 1 ha during the transition period between the wet and dry seasons. We shortened the measurement period as much as possible (i.e. 8 days) and limited measurements to daytime only (i.e. 9:00 a.m. to 4:30 p.m.). Furthermore, data from a continuous measurement system of soil respiration located in a nearby plot (see Bonal et al. 2008 for a detailed description) at the same site in Paracou, allowed us to characterise both within-day and between-day variations during this 8-day period. On this nearby plot, soil respiration was measured every half hour in three automated chambers and varied only slightly between 9:00 a. $\mathrm{m}$. and 4:30 p.m. with an average daily range of $0.5 \pm 0.1 \mathrm{~g}_{\mathrm{C}} \mathrm{m}^{-2} \mathrm{~d}^{-1}$. Between-day variations were only slightly larger (i.e. $0.9 \pm 0.2 \mathrm{~g}_{\mathrm{C} \mathrm{m}} \mathrm{m}^{-2} \mathrm{~d}^{-1}$ range over the same 8-day period), and these variations were mainly caused by a single rain event occurring on July 30th. Both within-day and betweenday variations appeared small compared to the $11.1 \mathrm{~g}_{\mathrm{C}} \mathrm{m}^{-2} \mathrm{~d}^{-1}$ range observed across our study plot. As a consequence, we considered that the proportion of temporal variations inevitably included in our data set is negligible as compared to spatial variations. The observed spatial variation in $R_{\text {soil }}$ (30\%), estimated through $\mathrm{CV}$ for measurements within the $10 \mathrm{~m}$-diameter subplots (i.e. $78.5 \mathrm{~m}^{2}$ ), was consistent with values obtained for other tropical forests in Malaysia (Katayama et al. 2009) and Indonesia (Ishizuka et al. 2005) where CVs of $33 \%$ and $36 \%$ were reported over $1,600 \mathrm{~m}^{2}(10 \times 10$ grid) and $567 \mathrm{~m}^{2}(8 \times 10$ grid $)$, respectively.

In another Malaysian forest, Kosugi et al. (2007) observed that the CVof $R_{\text {soil }}$ measurements increased with subplot size i.e. from $29 \%$ to $39 \%$ for plot size ranging from 25 to $2,500 \mathrm{~m}^{2}$, respectively. In our study, in contrast, the CVs calculated both at the whole plot level (32\%) and at the subplot level $(30 \%)$ were very similar. Our experimental plot was free of gaps and characterised by uniform soil conditions. This may explain the low variation we observed among subplots (13\%).

Forest structure contributes to explaining spatial variation in litterfall and root mass

In order to describe the influence of the forest structure on $R_{\text {soil }}$, we calculated an individual tree local contribution index $\left(I_{c}\right)$ based on its trunk cross section area. The sum of the tree local contribution indices $\left(\sum I_{c}\right)$, though simplistic (i.e. tree influence was considered isotropic and proportional to its size, no competition or interspecific difference was accounted for), was significantly and positively correlated with litterfall $\left(\mathrm{R}^{2}=0.61\right)$ and root mass $\left(\mathrm{R}^{2}=0.94\right)$. This confirms the assumption that local spatial patterns in litter production and root mass do 

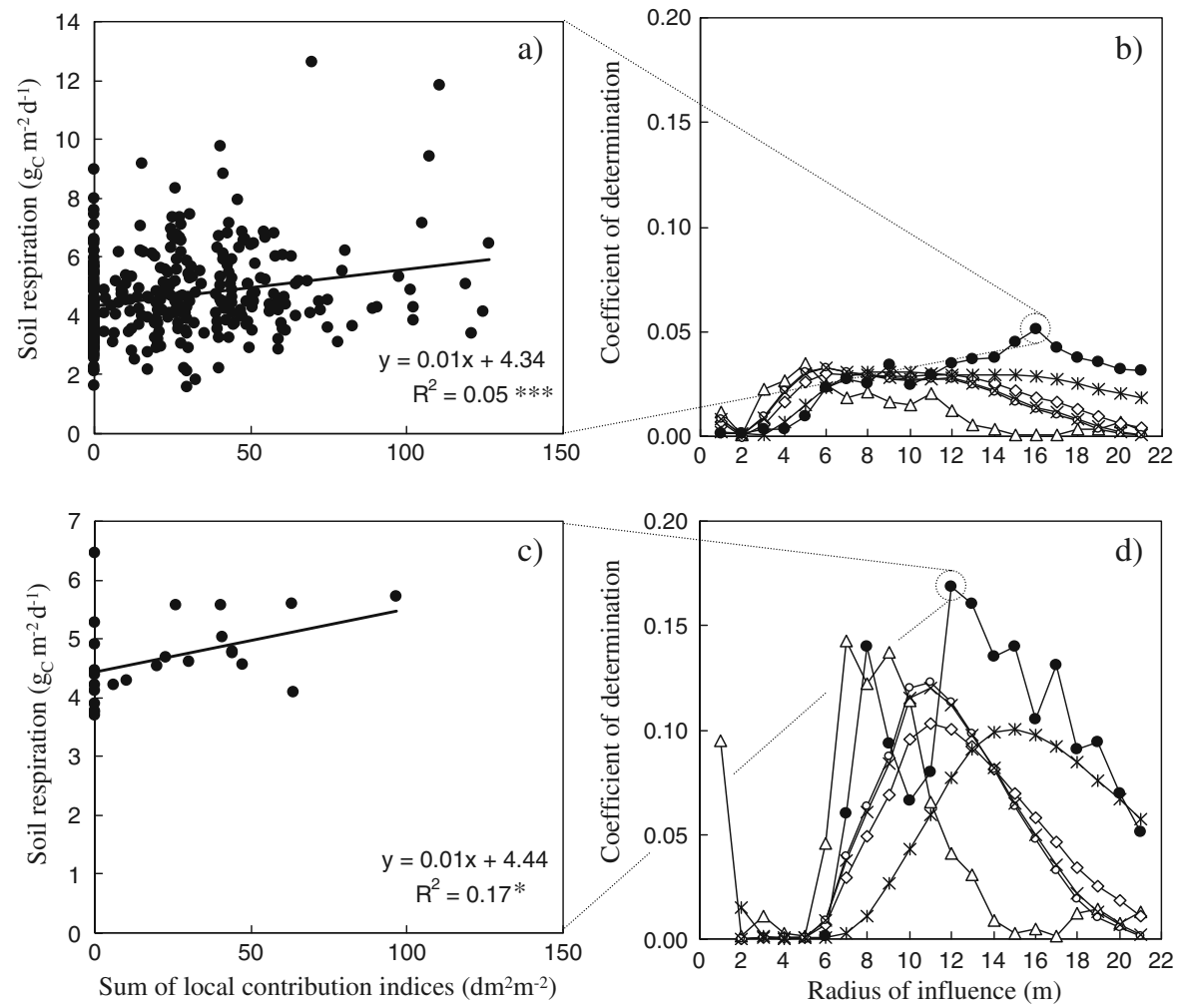

Fig. 4 Relationships between the sum of local contribution indices of surrounding trees within the fitted radius of influence $\left(\sum I_{c}\right)$ and a) soil respiration $\left(R_{\text {soil }}\right)$ at the collar scale or $\left.\mathbf{c}\right)$ soil respiration $\left(R_{\text {soil }}\right)$ at the subplot scale. The best relationship obtained with M6 and the following adjustment: $a=1.4$, $b=0.00026$ and $r_{\max }=16 \mathrm{~m} ; p<0.001, n=319$ for $R_{\text {soil }}$ at the collar scale and with M6 and the following adjustment: $a=1.8$,

depend on tree distribution. Ferrari and Sugita (1996) found in hemlock-hardwood forests that leaf litterfall dispersal around the trunk declined exponentially with distance, the radius of influence ranging from 7.9 to $29.3 \mathrm{~m}$ depending on the tree species. Several factors might affect the pattern of litterfall distribution on the forest floor: exogenous factors such as rain and wind (Staelens et al. 2003), and endogenous factors. Among the latter, tree phenology and architecture differ greatly among species (127 species were identified in our experimental plot) and individuals (e.g. trunk diameter from 10 to $97 \mathrm{~cm}$ in our plot). Despite the numerous sources of variation in natural forests and despite crown heterogeneity (i.e. anisotropy), we observed a significant relationship between leaf litterfall and $\sum I_{c}\left(\mathrm{R}^{2}=0.61\right)$ with a radius of influence of $7 \mathrm{~m}$ when $I_{c}$ was calculated with a uniform model (M1). Similarly, the most significant

$b=0.00026$ and $r_{\max }=12 \mathrm{~m} ; p<0.05, n=25$ for $R_{\text {soil }}$ at the subplot scale are shown here. Variations in the strength of the relationship between $\sum I_{c}$ and b) $R_{\text {soil }}$ at the collar scale $(n=319)$ or d) $R_{\text {soil }}$ at the subplot scale $(n=25)$, according to the distance of influence of the trees used in the calculation of the index. See legend for Fig. 2

relationship between root mass and $\sum I_{c}$ was found for $I_{c}$ modelled with a linear equation (M2). An interpretation of this result is difficult because the spatial variation in root mass, the root colonisation front, competition among roots and root lifespan are unknown. Nevertheless, our estimation of the radius of influence of tree roots $(r=7 \mathrm{~m})$ was in the same range as values from the few reliable measurements of tree root lengths reported in tropical forests. For instance, for three abundant tree species in the Guianan tropical forest, it has been found that root systems extend horizontally 4.0-15.0 m away from the trunk (Atger and Edelin 1994). In a tropical forest in Borneo, the roots of Dipterocarpaceae trees (with $\mathrm{dbh} \geq 60 \mathrm{~cm})$ spread 4.0-11.4 $\mathrm{m}(n=8)$ from the trunk (Katayama et al. 2009). Similarly, the average lateral extension of buttress roots from the trunk of Microberlinia bisulcata (Caesalpiniaceae) in a central African 
rain forest (dbh 102-252 cm) is $7.4 \mathrm{~m}$, but can exceed $20 \mathrm{~m}$ (Newbery et al. 2009).

Forest structure accounts poorly for local variations in soil respiration

The influence of forest structure on the spatial variation of $R_{\text {soil }}$ has been assessed in other tropical forests through the relationship observed between basal area and $R_{\text {soil }}$ measurements. Patterns differed according to location. Katayama et al. (2009) showed a significant relationship between $R_{\text {soil }}$ and forest structural parameters such as mean diameter at breast height, total basal area, and maximum diameter at breast height within $6 \mathrm{~m}$ from the measurement points. These results did not corroborate the findings of Sotta et al. (2004), who reported that $R_{\text {soil }}$ was not correlated with the basal area in an Amazonian site. In accordance with this latter result, mean $R_{\text {soil }}$ estimated in our plot was not correlated with the basal area calculated for the subplot area.

When considering spatial variation in soil respiration at collar level, we found no relationship between $R_{\text {soil }}$ and the influence of trees (estimated as a function of tree cross section area and distance from the trunk). In contrast, at the subplot level, a significant relationship was found: the best model, explaining $17 \%$ of the spatial variation in $R_{\text {soil }}$, has a power form with a radius of local tree influence equal to $12 \mathrm{~m}$. This result clearly indicates that, among trees greater than $10 \mathrm{~cm} \mathrm{dbh}$, the biggest trees have a stronger and wider impact on soil respiration than smaller trees. This observation is consistent with results from a Finnish Scots pine forest where smaller trees were less important than big trees in inducing spatial heterogeneity and in structuring properties of the humus layer (Kuuluvainen and Linkosalo 1998).

Due to the difficulty in measuring the spatial variations of root mass and litterfall, our sample sizes were small for these variables $(n=5$ and $n=8$, respectively). Although this could be considered a limiting factor in our study, correlations between tree local contribution $\left(I_{c}\right)$ and both litterfall and root mass were strong. This is an important finding for future studies at regional scales where large datasets will be easier to gather for $\mathrm{dbh}$ than for root mass and litterfall. Aside from these limitations, the remaining unexplained variance in spatial heterogeneity of $R_{\text {soil }}$ remains large $(83 \%)$. Several other processes could explain spatial variation in $R_{\text {soil }}$. Firstly, differences in tree species composition and local assemblages may contribute to spatial patterns of soil properties (Kamei et al. 2009), including nitrification (Aubert et al. 2005), C and $\mathrm{N}$ mineralisation (Dijkstra et al. 2009), and soil respiration (Berger et al. 2010). Secondly, microbial respiration depends on litter quality (i.e. $\mathrm{C} / \mathrm{N}$ ratio, $\mathrm{N}$ content) which governs its decomposability, and large spatial variation in litter quality were observed in the same experimental forest plots (Hättenschwiler et al. 2008). Finally, root respiration depends on root quality: fine or coarse root $\mathrm{N}$ concentrations promote root growth and maintenance activities, respectively (Vose and Bolstad 2006; Vose and Ryan 2002).

\section{Conclusion}

Our study showed that the spatial variation in soil respiration was poorly explained by forest structure (tree size and spatial arrangement), despite the fact that spatial heterogeneity of leaf litterfall and root mass was well-predicted by forest structure. This result suggests that the contribution of trees to soil functioning depends not only on their quantitative characteristics, but also on their qualitative traits. Spatial variation in leaf and root composition and phenology, fine root turnover, root exudates and rhizosphere organisms, which are closely linked to tree species, could influence the spatial heterogeneity of soil respiration at the subplot level.

Acknowledgements This research was supported by a $\mathrm{PhD}$ Grant from the French "Ministère de 1'Education Nationale et de la Recherche" to LB. The ORE "Ecosystèmes Forestiers" managed by GIP-Ecofor contributed to the funding of the field experiment. We are grateful to Jean-Yves Goret, Cyril Douthe and Louis Maire for their help during data acquisition in the field, to Pierre Chauvet for the geostatistical analyses, and to Amy Deacon for the improvement of the English writing. The helpful comments from two anonymous reviewers on a previous version of this article were greatly appreciated.

\section{References}

Adachi M, Bekku YS, Konuma A, Kadir WR, Okuda T, Koizumi H (2005) Required sample size for estimating soil respiration rates in large areas of two tropical forests and of two types of plantation in Malaysia. For Ecol Manag 210:455-459. doi:10.1016/j.foreco.2005.02.011 
Atger C, Edelin C (1994) Stratégies d'occupation du milieu souterrain par les systèmes racinaires des arbres. Rev Ecol (Terre Vie) 49:343-356

Aubert M, Bureau F, Vinceslas-Akpa M (2005) Sources of spatial and temporal variability of inorganic nitrogen in pure and mixed deciduous temperate forests. Soil Biol Biochem 37:67-79. doi:10.1016/j.soilbio.2004.07.025

Berger TW, Inselsbacher E, Zechmeister-Boltenstern S (2010) Carbon dioxide emissions of soils under pure and mixed stands of beech and spruce, affected by decomposing foliage litter mixtures. Soil Biol Biochem 42:986-997. doi:10.1016/j.soilbio.2010.02.020

Bonal D, Bosc A, Ponton S, Goret JY, Burban B, Gross P, Bonnefond JM, Elbers J, Longdoz B, Epron D, Guehl JM, Granier A (2008) Impact of severe dry season on net ecosystem exchange in the Neotropical rainforest of French Guiana. Glob Chang Biol 14:1917-1933. doi:10.1111/j.1365-2486.2008.01610.x

Bréchet L, Ponton S, Roy J, Freycon V, Couteaux MM, Bonal D, Epron D (2009) Do tree species characteristics influence soil respiration in tropical forests? A test based on 16 tree species planted in monospecific plots. Plant Soil 319:235-246. doi:10.1007/s11104-008-9866-Z

Brown D, Rothery P (1994) Models in biology: mathematics, statistics and computing. Wiley, Chichester

Buchmann N, Guehl J-M, Barigah TS, Ehleringer JR (1997) Interseasonal comparison of $\mathrm{CO}_{2}$ concentrations, isotopic composition, and carbon dynamics in an Amazonian rainforest (French Guiana). Oecologia 110:120-131

Chambers JQ, Tribuzy ES, Toledo LC, Crispim BF, Higuchi N, dos Santos J, Araujo AC, Kruijt B, Nobre AD, Trumbore SE (2004) Respiration from a tropical forest ecosystem: partitioning of sources and low carbon use efficiency. Ecol Appl 14:S72-S88. doi:10.1890/01-6012

Davidson EA, Verchot LV, Cattanio JH, Ackerman IL, Carvalho JEM (2000) Effects of soil water content on soil respiration in forests and cattle pastures of eastern Amazonia. Biogeochemistry 48:53-69. doi:10.1023/ A: 1006204113917

Dijkstra FA, West JB, Hobbie SE, Reich PB (2009) Antagonistic effects of species on $\mathrm{C}$ respiration and net $\mathrm{N}$ mineralization in soils from mixed coniferous plantations. For Ecol Manag 257:1112-1118. doi:10.1016/j.foreco.2008.11.014

Dixon RK, Brown S, Houghton RA, Solomon AM, Trexler MC, Wisniewski J (1994) Carbon pools and flux of global forest ecosystems. Science 263:185-190

Epron D, Nouvellon Y, Roupsard O, Mouvondy W, Mabiala A, Saint-Andre L, Joffre R, Jourdan C, Bonnefond J-M, Berbigier P, Hamel O (2004) Spatial and temporal variations of soil respiration in a Eucalyptus plantation in Congo. For Ecol Manag 202:149-160. doi:10.1016/j. foreco.2004.07.019

Epron D, Bosc A, Bonal D, Freycon V (2006) Spatial variation of soil respiration across a topographic gradient in a tropical rainforest in French Guiana. J Trop Ecol 22:565574. doi:10.1017/S0266467406003415

Fang C, Moncrieff JB, Gholz HL, Clark KL (1998) Soil $\mathrm{CO}_{2}$ efflux and its spatial variation in a Florida slash pine plantation. Plant Soil 205:135-146. doi:10.1023/ A:1004304309827
FAO-ISRIC-ISSS (1998) World reference base for soil resources. World soil resources reports, vols. 84. Food and Agricultural Organisation, Rome

Ferrari JB, Sugita S (1996) A spatially explicit model of leaf litter fall in hemlock-hardwood forests. Can J For Res 26:1905-1913

Gourlet-Fleury S, Ferry B, Molino J-F, Petronelli P, Schmitt L (2004) Experimental plots: key features. In: Gourley-Fleury S, Guehl J-M, Laroussinie O (eds) Ecology and management of a Neotropical rainforest. Elsevier, Paris, pp 3-30

Guehl JM, Domenach AM, Bereau M, Barigah TS, Casabianca H, Ferhi A, Garbaye J (1998) Functional diversity in an Amazonian rainforest of French Guyana: a dual isotope approach $(\delta 15 \mathrm{~N}$ and $\delta 13 \mathrm{C})$. Oecologia 116:316-330

Hättenschwiler S, Aeschlimann B, Couteaux MM, Roy BD (2008) High variation in foliage and leaf litter chemistry among 45 tree species of a neotropical rainforest community. New Phytol 179:165-175. doi:10.1111/j.14698137.2008.02438.x

Ishizuka S, Iswandi A, Nakajima Y, Yonemura L, Sudo S, Tsuruta H, Muriyarso D (2005) Spatial patterns of greenhouse gas emission in a tropical rainforest in Indonesia. Nutr Cycl Agroecosyst 71:55-62. doi:10.1007/s10705-004-5284-7

Janssens IA, Barigah TS, Ceulemans R (1998) Soil $\mathrm{CO}_{2}$ efflux rates in different tropical vegetation types in French Guiana. Ann For Sci 55:671-680. doi:10.1051/forest:19980603

Kamei J, Pandey HN, Barik SK (2009) Tree species distribution and its impact on soil properties, and nitrogen and phosphorus mineralization in a humid subtropical forest ecosystem of Northeastern India. Can J For Res 39:36-47

Katayama A, Kume T, Komatsu H, Ohashi M, Nakagawa M, Yamashita M, Otsuki K, Suzuki M, Kumagai T (2009) Effect of forest structure on the spatial variation in soil respiration in a Bornean tropical rainforest. Agric For Meteorol 149:1666-1673. doi:10.1016/j.agrfor met.2009.05.007

Kosugi Y, Mitani T, Ltoh M, Noguchi S, Tani M, Matsuo N, Takanashi S, Ohkubo S, Nik AR (2007) Spatial and temporal variation in soil respiration in a Southeast Asian tropical rainforest. Agric For Meteorol 147:35-47. doi:10.1016/j.agrformet.2007.06.005

Kuuluvainen T, Linkosalo T (1998) Estimation of a spatial treeinfluence model using iterative optimization. Ecol Model 106:63-75. doi:10.1016/S0304-3800(97)00182-8

Martin JG, Bolstad PV (2009) Variation of soil respiration at three spatial scales: components within measurements, intra-site variation and patterns on the landscape. Soil Biol Biochem 41:530-543. doi:10.1016/j.soilbio.2008.12.012

Metcalfe DB, Meir P, Aragao L, Malhi Y, da Costa ACL, Braga A, Goncalves PHL, de Athaydes J, de Almeida SS, Williams M (2007) Factors controlling spatio-temporal variation in carbon dioxide efflux from surface litter, roots, and soil organic matter at four rain forest sites in the eastern Amazon. J Geophys Res 112:1-9. doi: G0400110.1029/2007jg000443

Negrete-Yankelevich S, Fragoso C, Newton AC, Russell G, Heal OW (2006) Spatial patchiness of litter, nutrients and macroinvertebrates during secondary succession in a tropical montane cloud forest in Mexico. Plant Soil 286:123-139. doi:10.1007/s11104-006-9031-5 
Newbery DM, Schwan S, Chuyong GB, van der Burgt XM (2009) Buttress form of the central African rain forest tree Microberlinia bisulcata, and its possible role in nutrient acquisition. Trees Struct Funct 23:219-234. doi:10.1007/ s00468-008-0270-3

Ohashi M, Kume T, Yamane S, Suzuki M (2007) Hot spots of soil respiration in an Asian tropical rainforest. Geophys Res Lett 34:1-4. doi:10.1029/2007GL029587

Raich JW, Potter CS (1995) Global patterns of carbon dioxide emissions from soils. Glob Biogeochem Cycles 9:23-36

Raich JW, Schlesinger WH (1992) The global carbon dioxide flux in soil respiration and its relationship to vegetation and climate. Tellus 44:81-99

Schwendenmann L, Veldkamp E, Brenes T, O'Brien JJ, Mackensen J (2003) Spatial and temporal variation in soil $\mathrm{CO}_{2}$ efflux in an old-growth neotropical rain forest, $\mathrm{La}$ Selva, Costa Rica. Biogeochemistry 64:111-128. doi:10.1023/A:1024941614919

Silver WL, Thompson AW, McGroddy ME, Varner RK, Dias JD, Silva H, Crill PM, Keller M (2005) Fine root dynamics and trace gas fluxes in two lowland tropical forest soils. Glob Chang Biol 11:1-17. doi:10.1111/j.13652486.2005.00903.x

Soe ARB, Buchmann N (2005) Spatial and temporal variations in soil respiration in relation to stand structure and soil parameters in an unmanaged beech forest. Tree Physiol 25:1427-1436. doi:10.1093/treephys/25.11.1427

Sotta ED, Meir P, Malhi Y, Nobre AD, Hodnett M, Grace J (2004) Soil $\mathrm{CO}_{2}$ efflux in a tropical forest in the central Amazon. Glob Chang Biol 10:601-617. doi:10.1111/ j.1529-8817.2003.00761.x

Staelens J, Nachtergale L, Luyssaert S, Lust N (2003) A model of wind-influenced leaf litterfall in a mixed hardwood forest. Can J For Res 33:201-209. doi:10.1139/x02-174

van der Werf GR, Morton DC, DeFries RS, Olivier JGJ, Kasibhatla PS, Jackson RB, Collatz GJ, Randerson JT (2009) $\mathrm{CO}_{2}$ emissions from forest loss. Nat Geosci 2:737738. doi:10.1038/ngeo671

Vincent G, Shahriari AR, Lucot E, Badot P-M, Epron D (2006) Spatial and seasonal variations in soil respiration in a temperate deciduous forest with fluctuating water table. Soil Biol Biochem 38:2527-2535. doi:10.1016/j.soil bio.2006.03.009

Vose JM, Bolstad PV (2006) Biotic and abiotic factors regulating forest floor $\mathrm{CO}_{2}$ flux across a range of forest age classes in the Southern Appalachians. Pedobiologia 50:577-587. doi:10.1016/j.pedobi.2006.10.006

Vose JM, Ryan MG (2002) Seasonal respiration of foliage, fine roots, and woody tissues in relation to growth, tissue $\mathrm{N}$, and photosynthesis. Glob Chang Biol 8:182-193. doi:10.1046/j.1365-2486.2002.00464.x 